\title{
Difference in the nature of tannins on in vitro ruminal methane and volatile fatty acid production and on methanogenic archaea and protozoal populations
}

\author{
R. Bhatta, ${ }^{* 1}$ Y. Uyeno,† K. Tajima, ${ }^{*}$ A. Takenaka, ${ }^{*}$ Y. Yabumoto, ${ }^{*}$ I. Nonaka, ${ }^{*}$ O. Enishi, ${ }^{*}$ and M. Kurihara* \\ *National Institute of Livestock and Grassland Science, Tsukuba 305-0901 Japan \\ †National Institute of Advanced Industrial Science and Technology, Tsukuba 305-0901 Japan
}

\section{ABSTRACT}

Six plant sources of hydrolyzable tannins (HT) or $\mathrm{HT}$ and condensed tannins (CT; designated as HT1, $\mathrm{HT} 2, \mathrm{HT} 3, \mathrm{HT}+\mathrm{CT} 1, \mathrm{HT}+\mathrm{CT} 2$, and $\mathrm{HT}+\mathrm{CT} 3)$ were evaluated to determine their effects in vitro on $\mathrm{CH}_{4}$ production and on ruminal archaeal and protozoa populations, and to assess potential differences in biological activities between sources containing HT only or HT and CT. Samples HT1, HT2, and HT3 contained only HT, whereas samples HT + CT1, HT + CT2, and $\mathrm{HT}+\mathrm{CT} 3$ contained HT and CT. In experiment 1 , in vitro incubations with samples containing $\mathrm{HT}$ or HT $+\mathrm{CT}$ resulted in a decrease in $\mathrm{CH}_{4}$ production of 0.6 and $5.5 \%$, respectively, compared with that produced by incubations containing the added tannin binder polyethylene glycol-6000. Tannin also suppressed the population of methanogenic archaea in all incubations except those with HT2, with an average decrease of $11.6 \%$ in HT incubations $(15.8,7.09$, and 12.0 in HT1, HT2, and HT3) and $28.6 \%$ in incubations containing $\mathrm{HT}+\mathrm{CT}(35.0,40.1$, and 10.8 in HT + CT1, HT + $\mathrm{CT} 2$, and HT + CT3) when compared with incubations containing added polyethylene glycol-6000. The mean decrease in protozoal counts was $12.3 \%$ in HT and $36.2 \%$ in HT + CT incubations. Tannins increased in vitro $\mathrm{pH}$, reduced total VFA concentrations, increased propionate concentrations, and decreased concentrations of iso-acids. In experiment 2, when a basal diet was incubated with graded levels of $\mathrm{HT}+\mathrm{CT} 1, \mathrm{HT}+$ $\mathrm{CT} 2$, and $\mathrm{HT}+\mathrm{CT} 3$, the total gas and $\mathrm{CH}_{4}$ production and archaeal and protozoal populations decreased as the concentration of tannins increased. Our results confirm that tannins suppress methanogenesis by reducing methanogenic populations in the rumen either directly or by reducing the protozoal population, thereby reducing methanogens symbiotically associated with the protozoal population. In addition, tannin sources contain-

Received June 10, 2008.

Accepted July 29, 2009

${ }^{1}$ Corresponding author: ragha0209@yahoo.com ing both $\mathrm{HT}$ and $\mathrm{CT}$ were more potent in suppressing methanogenesis than those containing only HT.

Key words: tannin, methane, methanogenic archaea, protozoon

\section{INTRODUCTION}

Ruminal methanogenic organisms use hydrogen produced during carbohydrate fermentation to reduce $\mathrm{CO}_{2}$ to $\mathrm{CH}_{4}$, thereby maintaining low partial pressures of hydrogen, which allows the oxidation of reduced NAD (Schonhusen et al., 2003). Despite this beneficial role in the rumen microbial ecosystem, the production of $\mathrm{CH}_{4}$ is an energetically wasteful process to ruminants (Anderson et al., 2003). Methane emission by ruminants has received considerable attention because of its contribution to global warming (Lassey, 2007). Therefore, $\mathrm{CH}_{4}$ reduction strategies should improve ruminant production efficiency and mitigate global warming.

Direct ruminal intervention is a means to control ruminant $\mathrm{CH}_{4}$ emissions (Joblin, 1999), because $\mathrm{CH}_{4}$ producing archaea, known as methanogens, are a distinct group of organisms that form a normal component of the rumen microbial ecosystem (Tavendale et al., 2005). Hydrogen and $\mathrm{CO}_{2}$ are the major substrates for ruminal methanogens, and compounds that inhibit the activity of methanogens are likely to reduce or eliminate $\mathrm{CH}_{4}$ production. Based on their structure and chemical properties, tannins are divided into hydrolyzable tannins $[\mathbf{H T}$, which have a central carbohydrate core to which number of phenolic carboxylic acids are bound by esters of gallic acid (gallotannin) or ellagic acid (ellagitannins)] and condensed tannins (CT, or proanthocyanidines, which have no carbohydrate core and are derived by condensation of flavonoid precursors or polymers of flavonoids; Baker, 1999). Although tannins are generally regarded as antinutritional, certain tannins at low concentrations alter ruminal fermentation (Bhatta et al., 2002) and microbial protein synthesis (Bhatta et al., 2001). Tannins also reduce ruminal $\mathrm{CH}_{4}$ production when included either as temperate legumes (Waghorn et al., 2002) or as purified tannin extracts 
Table 1. Nutrient composition of the TMR, hydrolyzable tannins $(\mathrm{HT})$, or hydrolyzable and condensed tannins $(\mathrm{HT}+\mathrm{CT})^{1}$

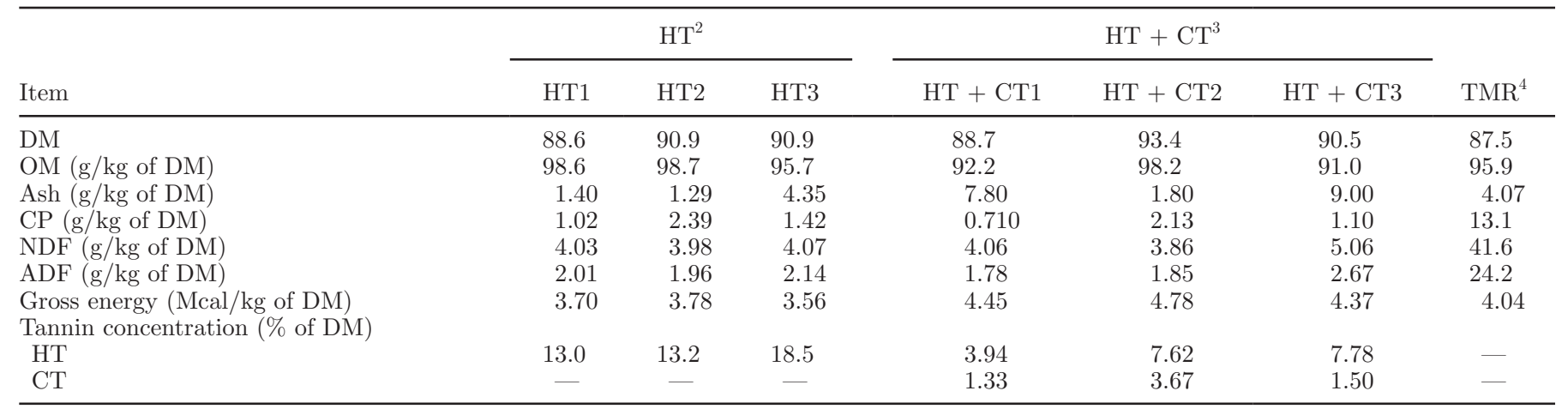

${ }^{1} \mathrm{HT}=$ hydrolyzable tannin as gallotannin; $\mathrm{CT}=$ condensed tannin as leucocyanidin equivalent.

${ }^{2} \mathrm{HT} 1, \mathrm{HT} 2$, and HT3 = samples containing only HT (HT1 from myrabolam; HT2 and HT3 from chestnut).

${ }^{3} \mathrm{HT}+\mathrm{CT} 1, \mathrm{HT}+\mathrm{CT} 2$, and HT + CT3 = samples containing HT plus CT $(\mathrm{HT}+\mathrm{CT} 1$ and HT + CT2 from quebracho; HT + CT3 from mimosa).

${ }^{4} \mathrm{TMR}$ contained $65 \%$ timothy hay, $20 \%$ crushed corn, and $15 \%$ soybean meal.

(Roth et al., 2002). However, there are no reports on potential differences in the activities of HT and CT on $\mathrm{CH}_{4}$ production and on methanogenic archaeal and ciliated protozoal populations. The present study was conducted to determine the effects of plant materials containing different tannins (HT or HT $+\mathrm{CT}$ ) on in vitro $\mathrm{CH}_{4}$ production and on ruminal archaeal and ciliated protozoal populations, and to determine the difference, if any, in tannin sources containing HT only or both HT and CT.

\section{MATERIALS AND METHODS}

\section{Source of Tannins}

Six commercially available natural sources of tannins (designated as HT1, HT2, HT3, HT + CT1, HT + CT2, and HT + CT3) were used in this study. According to information obtained from the supplier (Kawamura and Co. Ltd., Asakusabashi, Taito-ku, Tokyo, Japan), HT1 (130 g of HT/kg of DM) was an extract from myrabolam, HT2 (132 $\mathrm{g}$ of $\mathrm{HT} / \mathrm{kg}$ of DM) and HT3 (185 g of HT $/ \mathrm{kg}$ of DM) were from chestnut, HT $+\mathrm{CT} 1(39.4 \mathrm{~g}$ of $\mathrm{HT} / \mathrm{kg}$ of $\mathrm{DM}+13.3 \mathrm{~g}$ of CT $/ \mathrm{kg}$ of $\mathrm{DM})$ and $\mathrm{HT}+\mathrm{CT} 2(76.2 \mathrm{~g}$ of $\mathrm{HT} / \mathrm{kg}$ of $\mathrm{DM}+36.7 \mathrm{~g}$ of $\mathrm{CT} / \mathrm{kg}$ of DM) were from quebracho, and $\mathrm{HT}+\mathrm{CT} 3$ $(77.8 \mathrm{~g}$ of $\mathrm{HT} / \mathrm{kg}$ of DM $+15.0 \mathrm{~g}$ of CT $/ \mathrm{kg}$ of DM) was from mimosa (Table 1). The products were supplied in the form of a fine dry powder.

\section{Tannin Estimation}

A 0.1-g sample of each tannin source was extracted with $10 \mathrm{~mL}$ of $70 \%$ (vol/vol) aqueous acetone in a 50$\mathrm{mL}$ stoppered Erlenmeyer flask for $20 \mathrm{~h}$ at room tem- perature. After centrifugation at $2,795 \times g$ for $15 \mathrm{~min}$, the supernatant was made up to $10 \mathrm{~mL}$ with butanol $\mathrm{HCl}$ in the presence of iron, using rhodanine reagent (Makkar, 2003). Condensed tannin was expressed as leucocyanidin equivalent and hydrolyzable tannin as gallotannin (Makkar, 2003).

\section{In Vitro Gas Production}

In vitro gas production was determined by the procedure of Menke and Steingass (1988). In experiment 1 (with tannin-containing samples only), the effects of the different tannin-containing samples on in vitro methanogenesis was assessed by incubating samples with and without addition of a tannin binder, polyethylene glycol (PEG; PEG-6000, Wako Pure Chemical Industries Ltd., Osaka, Japan; $400 \mathrm{mg})$. Tannin-containing samples (200 mg) were weighed into 100-mL calibrated glass syringes (Häberle Labortechnik, Ettlenschieß, Germany) with pistons lubricated with Vaseline. Buffered mineral solution (Menke and Steingass, 1988) was prepared and placed in a water bath at $39^{\circ} \mathrm{C}$ under continuous flushing with $\mathrm{CO}_{2}$. Rumen fluid was collected before the morning feeding from 3 ruminally cannulated, nonlactating Holstein cows (466 kg of mean BW) fed 5.8 $\mathrm{kg}$ of timothy hay, $1.6 \mathrm{~kg}$ of crushed corn, and 0.80 $\mathrm{kg}$ of soybean meal. Ruminal contents were collected into a prewarmed insulated flask, transported to the laboratory, homogenized, and filtered through 3 layers of cheesecloth. An anaerobic condition was maintained by continuous flushing with $\mathrm{CO}_{2}$. The well-mixed and $\mathrm{CO}_{2}$-flushed, strained ruminal fluid was added to the buffered mineral solution (1:2). The mixture was kept stirred with a magnetic stirrer under $\mathrm{CO}_{2}$ in a water bath at $39^{\circ} \mathrm{C}$. A mixture of ruminal fluid and buffer 
$(30 \mathrm{~mL})$ was dispensed into each syringe containing the weighed tannin samples. After closing the clips on the silicon tube at the syringe tip, syringes were gently shaken and clips were opened to remove gas by pushing the piston upward to achieve complete gas removal. The clip was closed, the initial volume was recorded, and the syringes were immediately placed in a thermostatically controlled shaking water bath at $39^{\circ} \mathrm{C}$. Incubation of each tannin sample was set up in triplicate, and incubations were repeated 3 times, with intervals of $1 \mathrm{wk}$ to obtain 9 observations for each feed sample. Incubations without a feed sample served as blanks. A parallel incubation of reference standard feedstuffs (hay and concentrate) obtained from the Hohenheim University (Hohenheim, Germany), as suggested by Menke et al. (1979), was also included. The gas produced after $24 \mathrm{~h}$ was recorded and gas samples were collected in evacuated vials and analyzed for $\mathrm{CH}_{4}$.

In experiment 2 (tannin-containing samples added to a basal diet), $200 \mathrm{mg}$ of $\mathrm{DM}$ of a basal diet consisting of timothy hay (65\%), crushed corn (20\%), and soybean meal $(15 \%)$ was incubated as described in experiment 1 with different levels of HT + CT1, HT + CT2, and HT + CT3. Samples containing CT were chosen because of the significant $(P<0.001)$ reduction in $\mathrm{CH}_{4}$ production observed in experiment 1 . The tannin samples were included at levels of $0,5,10,15,20$, and $25 \%$ of the basal diet DM.

\section{$\mathrm{CH}_{4}$ Analysis}

The concentration of $\mathrm{CH}_{4}$ in the collected gas samples was analyzed in a gas chromatograph (GC8A, Shimadzu Corp., Kyoto, Japan) with a stainless steel column (Polapack type Q, 80/100 mesh, Waters Associates Inc., Milford, MA), and a C-R3A integrator (Shimadzu). The column temperature was maintained at $50^{\circ} \mathrm{C}$ and $\operatorname{Ar}\left(0.5 \mathrm{~kg} / \mathrm{cm}^{2}\right)$ was used as the carrier gas. A mixture of $\mathrm{H}(1.04 \%), \mathrm{CH}_{4}(22.8 \%), \mathrm{CO}_{2}(33.6 \%)$, and $\mathrm{N}_{2}(42.5 \%)$ served as the standard (Kajikawa et al., 2007).

\section{Nutrient Analysis}

Basal diet and tannin-containing samples were analyzed for DM, total N, ether extract, ash (AOAC, 1990), NDF (Van Soest et al., 1991), and ADF (Robertson and Van Soest, 1981). The NDF was analyzed in diet samples without sodium sulfite (with sodium sulfite in tannin samples) and with the use of a heat stable-amylase. Both NDF and ADF were expressed with residual ash. Gross energy content of samples was determined in an adiabatic bomb calorimeter (CA-4 PJ, Shimadzu).

\section{Rumen Fluid Analysis}

Volatile fatty acids were determined (Tajima et al., 2007 ) by gas chromatography (6890 series gas chromatograph with a flame-ionization detector, HewlettPackard, Wilmington, DE) on a glass column with 5\% Thermon 1000 and $0.5 \% \mathrm{H}_{3} \mathrm{PO}_{4}$ on 80/100 mesh Chromosorb W (Wako Pure Chemical Ltd., Osaka, Japan). Ammonia-N was determined colorimetrically (Tajima et al., 2007) with a Technicon Auto Analyzer II (Shimadzu).

\section{In Situ DM Digestibility}

Diet samples were ground to pass through a $2-\mathrm{mm}$ screen and were mixed with the required amount of tannin-containing materials. Five grams of each sample was weighed, placed into a nylon bag (made of polyester monofilament, $53 \mu \mathrm{m}$ pore size, $10 \times 20 \mathrm{~cm}$ bag), and incubated in 2 ruminally cannulated, nonlactating Holstein cows (466 kg of mean BW) fed $5.8 \mathrm{~kg}$ of timothy hay, $1.6 \mathrm{~kg}$ of crushed corn, and $0.80 \mathrm{~kg}$ of soybean meal with vitamin and mineral supplements. After a 48-h in situ incubation, bags were removed and immediately placed in cold water to stop fermentation and to remove feed particles adhering to the bags. Subsequently, bags were placed in a domestic washing machine and washed for $20 \mathrm{~min}$ in water at 22 to $25^{\circ} \mathrm{C}$. Bags were dried to a constant weight at $65^{\circ} \mathrm{C}$, cooled to room temperature in desiccators, and weighed to determine DM disappearance.

\section{Quantification of Archaeal and Bacterial 16S rRNA}

Ruminal fluid was clarified according to Whitford et al. (1998) and total RNA was extracted by the beadbeating method (Krause and Russell, 1996). After a 24-h in vitro incubation (experiments 1 and 2), rumen fluid samples were collected and total RNA was extracted with phenol equilibrated to $\mathrm{pH} 5.1$ with a buffer (10 $\mathrm{m} M$ EDTA, $50 \mathrm{~m} M$ sodium acetate, $\mathrm{pH} 5.1$; Uyeno et al., 2004). Deoxyribonucleic acid contamination was removed by treating samples with RNase-free DNase (Promega, Madison, WI). Total RNA was stored at $-80^{\circ} \mathrm{C}$ until analysis.

\section{rRNA Quantification}

The following probes (Uyeno et al., 2007) were used for the detection of bacterial and archaeal 16S rRNA: Arc915 (CCCCCGCCAATTCCTTTA; formamide concentration, 30\%; cleavage coefficient, 0.80) and Eub338 a mixture of equal amounts of 3 probes (GCTGCCTCCCGTAGGAGT, GCAGCCACCCGTAGGTGT, and 
GCTGCCACCCGTAGGTGT); formamide concentration, 20\%; cleavage coefficient, 0.96]. The sequencespecific cleavage of rRNA fragments was performed as described previously (Uyeno et al., 2004). Briefly, $10 \mu \mathrm{L}$ of RNA solution $(100 \mathrm{ng} / \mu \mathrm{L}), 5 \mu \mathrm{L}$ of $15 \times$ hybridization buffer [375 mM Tris-HCl (pH 7.5), $15 \mathrm{~m} M$ EDTA, $375 \mathrm{mM} \mathrm{NaCl}$ ], $2 \mu \mathrm{L}$ of oligonucleotide probe solution $(10 \mathrm{pmol} / \mu \mathrm{L})$, and a defined amount of formamide were mixed to make a hybridization solution, and diethyl pyrocarbonate-treated water was added to make a final volume of $75 \mu \mathrm{L}$. The mixture was subsequently heated at $95^{\circ} \mathrm{C}$ for $1 \mathrm{~min}$ to unfold the RNA molecules, and the mixture was kept at the hybridization-digestion temperature $\left(50^{\circ} \mathrm{C}\right)$ for $1 \mathrm{~min}$. To initiate the cleavage reaction, $25 \mu \mathrm{L}$ of preheated $4 \times$ enzyme solution [25 $\mathrm{m} M$ Tris (pH 7.5), $40 \mathrm{mM} \mathrm{MgCl}, 25 \mathrm{mM} \mathrm{NaCl}, 4 \mathrm{~m} M$ dithiothreitol, $120 \mathrm{mg}$ of BSA $/ \mathrm{mL}, 20 \mathrm{U} / \mu \mathrm{L}$ of cloned Ribonuclease H from Escherichia coli (TaKaRa, Kyoto, Japan)] was added to the mixture. After incubation at $50^{\circ} \mathrm{C}$ for $15 \mathrm{~min}, 50 \mu \mathrm{L}$ of stop solution [30 $\mathrm{m} M$ EDTA, $0.9 M$ sodium acetate ( $\mathrm{pH} 7.0)]$ was added to the mixture to terminate the reaction. The RNA in the mixture was purified by ethanol precipitation and subjected to electrophoresis by an Agilent 2100 bioanalyzer with an RNA 6000 nano kit (Agilent, Palo Alto, CA).

Signal intensities of the respective peaks in the electrophoresed bands were determined and converted to peak areas by the Biosizing software associated with the device. The percentage of cleaved small subunit (SSU) rRNA was calculated using the following equation: percentage of cleaved SSU rRNA in the total SSU rRNA $=(a+b) /(a+b+c) \times 100$, where $a$ and $b$ are the respective peak areas of fragmented SSU rRNA derived from the cleavage, and $\mathrm{c}$ is the intact (i.e., nonfragmented) SSU rRNA. The percentage was converted to the SSU rRNA population of the target group in total SSU rRNA by the following calculation: (SSU rRNA population of the target group $)=($ percentage of cleaved SSU rRNA)/(cleavage coefficient of the scissor probe). This equation measured values that were corrected with a coefficient to estimate the actual values of the population.

\section{Enumeration of Ciliated Protozoa}

After terminating the in vitro incubations of experiments 1 and 2, $1 \mathrm{~mL}$ of rumen fluid was diluted with $4 \mathrm{~mL}$ of saline containing formalin and $0.03 \%$ methyl green. Total ciliated protozoa in samples were counted using a Fuchs-Rosenthal chamber (0.2 mm depth, 2 $\times 2 \mathrm{~mm}$ chamber, $0.25 \mathrm{~mm}$ square lined) under $10 \times$ magnification in a microscope (type BH-2, Olympus Corporation, Tokyo, Japan; Ogimoto and Imai, 1981).

\section{Statistical Analysis}

Data $\left[\mathrm{NH}_{3}-\mathrm{N}\right.$, total VFA and $\mathrm{CH}_{4}$ concentrations, $16 \mathrm{~S}$ rRNA-based archaeal and bacterial populations, ciliated protozoal counts, and in vitro DM digestibility (IVDMD)] of tannin samples with and without PEG-6000 and the basal diet incubated with different levels of tannin samples were analyzed by the GLM procedure, using SAS/STAT version 9.1 (SAS Institute, 2004). The general model used was $Y i j=\mu+\alpha i+\beta j$ $+\alpha \beta i j+\varepsilon i j$, in which Yij is the dependent variable, $\mu$ is the least squares mean, $\alpha \mathrm{i}$ is the effect of tannins, $\beta \mathrm{j}$ is the effect of the PEG-6000, $\alpha \beta i \mathrm{ij}$ is the effect of the interaction of tannins and PEG-6000, and $\varepsilon \mathrm{ij}$ is the residual error. Treatment means were compared using Tukey's multiple comparisons procedure, and effects were considered significant at a probability value of $P$ $<0.05$.

\section{RESULTS}

Nutrient composition and tannin contents of samples are presented in Table 1. All samples had low CP, with the highest amount in HT2 (2.4\% of DM). Contents of both NDF and ADF were very low in all samples, possibly because the commercial samples used were in a fine powder; hence, considerable amounts were filtered through the crucible after detergent treatment. Gross energy was greater than $4.10 \mathrm{Mcal} / \mathrm{kg}$ in all samples. Total tannin $(\mathrm{HT}+\mathrm{CT})$ contents $(\%$ of DM) in $\mathrm{HT}+$ $\mathrm{CT} 1, \mathrm{HT}+\mathrm{CT} 2$, and HT + CT3 were 5.3, 11.3, and 9.3, respectively. The TMR contained $13.1 \% \mathrm{CP}$ and 4.04 Mcal of gross energy. The NDF and ADF were 41.6 and 24.2 (\% of DM), respectively. Tannin samples $\mathrm{HT}+\mathrm{CT} 1, \mathrm{HT}+\mathrm{CT} 2$, and HT + CT3, incubated at $0,5,10,15,20$, and $25 \%$ of the basal diet, provided total tannin concentrations (CT $+\mathrm{HT}$ ) of $0,0.27,0.53$, $0.79,1.06$, and $1.32 \%$ in the HT + CT1 incubation; $0,0.57,1.13,1.70,2.26$, and $2.83 \%$ in the HT + CT2 incubation; and $0,0.47,0.93,1.38,1.85$, and $2.33 \%$ in the HT + CT3 incubation.

\section{Total Gas Production, $\mathrm{CH}_{4}$ Production, and Rumen Microbial Population In Vitro}

Total gas production was lower $(P<0.001)$ in incubations containing tannin than in incubations containing tannin plus PEG-6000 (Table 2), and the difference was greater $(P<0.001)$ in HT $+\mathrm{CT}$ than in HT incubations. When PEG-6000 was added to incubations containing only $\mathrm{HT}$, gas production averaged approximately 5 $\mathrm{mL} / 200 \mathrm{mg}$ of DM, compared with $9.0,13.5$, and 9.0 $\mathrm{mL} / 200 \mathrm{mg}$ of DM for HT + CT1, HT + CT2, and 
Table 2. In vitro total gas and $\mathrm{CH}_{4}$ production from tannin samples ${ }^{1}$ with and without polyethylene glycol $(\mathrm{PEG})^{2}$

\begin{tabular}{|c|c|c|c|c|c|c|c|c|c|c|c|c|c|}
\hline \multirow[b]{2}{*}{ Item } & \multicolumn{6}{|c|}{$\mathrm{HT}^{3}$} & \multicolumn{6}{|c|}{$\mathrm{HT}+\mathrm{CT}^{4}$} & \multirow[b]{2}{*}{ SEM } \\
\hline & HT1 & $\begin{array}{c}\mathrm{HT} 1+ \\
\mathrm{PEG}\end{array}$ & HT2 & $\begin{array}{c}\mathrm{HT} 2+ \\
\mathrm{PEG}\end{array}$ & HT3 & $\begin{array}{c}\mathrm{HT} 3+ \\
\text { PEG }\end{array}$ & $\begin{array}{l}\mathrm{HT}+ \\
\mathrm{CT} 1\end{array}$ & $\begin{array}{c}\mathrm{HT}+\mathrm{CT} 1 \\
+ \text { PEG }\end{array}$ & $\begin{array}{c}\mathrm{HT}+ \\
\mathrm{CT} 2\end{array}$ & $\begin{array}{c}\mathrm{HT}+\mathrm{CT} 2 \\
+ \text { PEG }\end{array}$ & $\begin{array}{c}\mathrm{HT}+ \\
\text { CT3 }\end{array}$ & $\begin{array}{c}\mathrm{HT}+\mathrm{CT} 3 \\
+ \text { PEG }\end{array}$ & \\
\hline 24-h gas production $(\mathrm{mL} / 200 \mathrm{mg}$ of $\mathrm{DM})$ & $18.5^{\mathrm{de}}$ & $24.3^{\mathrm{b}}$ & $18.2^{\mathrm{e}}$ & $23.6^{\mathrm{b}}$ & $20.7^{\mathrm{c}}$ & $25.7^{\mathrm{a}}$ & $0.7^{\mathrm{h}}$ & $9.5^{\mathrm{f}}$ & $6.1^{\mathrm{g}}$ & $19.6^{\text {cd }}$ & $0.5^{\mathrm{h}}$ & $9.5^{\mathrm{f}}$ & 0.216 \\
\hline $\mathrm{CH}_{4}$ (\% of total gas) & $13.5^{\mathrm{bc}}$ & $13.5^{\mathrm{bc}}$ & $13.4^{\mathrm{bc}}$ & $12.5^{\mathrm{c}}$ & $8.76^{\mathrm{d}}$ & $9.33^{\mathrm{d}}$ & $15.1^{\mathrm{b}}$ & $20.2^{\mathrm{a}}$ & $14.7^{\mathrm{b}}$ & $19.7^{\mathrm{a}}$ & $13.8^{\mathrm{bc}}$ & $20.3^{\mathrm{a}}$ & 0.328 \\
\hline $\mathrm{CH}_{4}(\mathrm{~m} M / \mathrm{g}$ of $\mathrm{DM})$ & $0.57^{\mathrm{c}}$ & $0.75^{\mathrm{b}}$ & $0.56^{\mathrm{c}}$ & $0.69^{\mathrm{b}}$ & $0.42^{\mathrm{d}}$ & $0.55^{\mathrm{c}}$ & $0.02^{\mathrm{f}}$ & $0.43^{\mathrm{d}}$ & $0.20^{\mathrm{e}}$ & $0.86^{\mathrm{a}}$ & $0.02^{\mathrm{f}}$ & $0.43^{\mathrm{d}}$ & 0.01 \\
\hline
\end{tabular}

${ }^{\mathrm{a}-\mathrm{h}}$ Means within a row without a common superscript letter differ $(P<0.001)$.

${ }^{1} \mathrm{HT}=$ hydrolyzable tannin as gallotannin; $\mathrm{CT}=$ condensed tannin as leucocyanidin equivalent.

${ }^{2}$ Tannin sample and PEG (PEG-6000; Wako Pure Chemical Industries Ltd., Osaka, Japan) were incubated at a 1:2 ratio (wt/wt).

${ }^{3} \mathrm{HT} 1, \mathrm{HT} 2$, and HT3 = samples containing only HT (HT1 from myrabolam; HT2 and HT3 from chestnut).

${ }^{4} \mathrm{HT}+\mathrm{CT} 1, \mathrm{HT}+\mathrm{CT} 2$, and HT $+\mathrm{CT} 3=$ samples containing HT plus CT $(\mathrm{HT}+\mathrm{CT} 1$ and HT + CT2 from quebracho; HT + CT3 from mimosa).

Table 3. Effects on ruminal microbial population of hydrolyzable tannins (HT) or hydrolyzable and condensed tannins $(\mathrm{HT}+\mathrm{CT})^{1}$ with or without polyethylene glycol (PEG) addition $^{2}$

\begin{tabular}{|c|c|c|c|c|c|c|c|c|c|c|c|c|c|}
\hline \multirow[b]{2}{*}{ Item } & \multicolumn{6}{|c|}{$\mathrm{HT}^{3}$} & \multicolumn{6}{|c|}{$\mathrm{HT}+\mathrm{CT}^{4}$} & \multirow[b]{2}{*}{ SEM } \\
\hline & HT1 & $\begin{array}{c}\mathrm{HT} 1+ \\
\mathrm{PEG}\end{array}$ & HT2 & $\begin{array}{c}\mathrm{HT} 2+ \\
\mathrm{PEG}\end{array}$ & HT3 & $\begin{array}{c}\mathrm{HT} 3+ \\
\mathrm{PEG}\end{array}$ & $\mathrm{HT}+\mathrm{CT} 1$ & $\begin{array}{c}\mathrm{HT}+\mathrm{CT} 1 \\
+ \text { PEG }\end{array}$ & $\begin{array}{c}\mathrm{HT}+ \\
\mathrm{CT} 2\end{array}$ & $\begin{array}{c}\mathrm{HT}+\mathrm{CT} 2 \\
+\mathrm{PEG}\end{array}$ & $\begin{array}{c}\mathrm{HT}+ \\
\mathrm{CT} 3\end{array}$ & $\begin{array}{c}\mathrm{HT}+\mathrm{CT} 3 \\
+\mathrm{PEG}\end{array}$ & \\
\hline Archaea (\% of $16 \mathrm{~S}$ rRNA) & $9.4^{\mathrm{e}}$ & $11.1^{\mathrm{cd}}$ & $11.8^{\mathrm{bcd}}$ & $12.7^{\mathrm{ab}}$ & $11.0^{\mathrm{d}}$ & $12.5^{\mathrm{ab}}$ & $8.0^{\mathrm{f}}$ & $12.3^{\text {bcd }}$ & $7.0^{\mathrm{f}}$ & $11.8^{\mathrm{bcd}}$ & $12.4^{\mathrm{bc}}$ & $13.9^{\mathrm{a}}$ & 0.27 \\
\hline Bacteria (\% of $16 \mathrm{~S}$ rRNA) & $80.2^{\mathrm{ab}}$ & $80.1^{\mathrm{ab}}$ & $81.2^{\mathrm{ab}}$ & $81.1^{\mathrm{ab}}$ & $76.9^{\mathrm{bc}}$ & $70.2^{\mathrm{d}}$ & $51.4^{\mathrm{e}}$ & $33.4^{\mathrm{g}}$ & $81.8^{\mathrm{ab}}$ & $71.1^{\mathrm{cd}}$ & $73.1^{\text {cd }}$ & $42.2^{\mathrm{f}}$ & 1.2 \\
\hline Total protozoa $(\times 10,000 / \mathrm{mL})$ & $5.27^{\mathrm{b}}$ & $5.90^{\mathrm{ab}}$ & $4.18^{\mathrm{d}}$ & $4.78^{\mathrm{c}}$ & $5.23^{\mathrm{b}}$ & $6.06^{\mathrm{a}}$ & $2.38^{\mathrm{g}}$ & $2.70^{\mathrm{f}}$ & $1.80^{\mathrm{h}}$ & $3.24^{\mathrm{e}}$ & $1.60^{\mathrm{i}}$ & $3.36^{\mathrm{e}}$ & 1.0 \\
\hline
\end{tabular}

${ }^{\mathrm{a}-\mathrm{i} M e a n s}$ within a row without a common superscript letter differ $(P<0.001)$.

${ }^{1} \mathrm{HT}=$ hydrolyzable tannin as gallotannin; $\mathrm{CT}=$ condensed tannin as leucocyanidin equivalent.

${ }^{2}$ Tannin samples and PEG (PEG-6000; Wako Pure Chemical Industries Ltd., Osaka, Japan) were incubated at a 1:2 ratio (wt/wt).

${ }^{3} \mathrm{HT} 1, \mathrm{HT} 2$, and HT3 = samples containing only HT (HT1 from myrabolam; HT2 and HT3 from chestnut).

${ }^{4} \mathrm{HT}+\mathrm{CT} 1, \mathrm{HT}+\mathrm{CT} 2$, and HT + CT3 = samples containing HT plus CT (HT + CT1 and HT + CT2 from quebracho; HT + CT3 from mimosa). 
HT + CT3, respectively (Table 2). Incubations with $\mathrm{HT}+\mathrm{CT} 1, \mathrm{HT}+\mathrm{CT} 2$, and $\mathrm{HT}+\mathrm{CT} 3$ produced 5.1, 5.0, and $6.5 \%$ less $\mathrm{CH}_{4}(P<0.001)$ than incubations containing added PEG-6000 (Table 2). On average, decreases in $\mathrm{CH}_{4}$ output were 0.6 and $5.5 \%$ in the $\mathrm{HT}$ and $\mathrm{HT}+\mathrm{CT}$ incubations, respectively, when compared with incubations containing added PEG-6000. When expressed as $\mathrm{m} M$ per gram of DM, the HT1, HT2, and HT3 incubations produced 23.6, 18.7, and 23.8\% less $\mathrm{CH}_{4}(P<0.05)$ and the $\mathrm{HT}+\mathrm{CT} 1, \mathrm{HT}+\mathrm{CT} 2$, and HT + CT3 incubations produced 94.4, 76.9, and 85.8\% less $\mathrm{CH}_{4}(P<0.001)$ than their respective incubations containing tannin plus PEG-6000.

Tannin suppressed $(P<0.001)$ the populations of methanogenic archaea in all incubations except those containing HT2, compared with the PEG-6000supplemented incubations. The average decrease was approximately $11.6 \%$ in the HT incubations $(15.8,7.09$, and $12.0 \%$ in the HT1, HT2, and HT3 incubations , respectively), compared with $28.6 \%$ in the $\mathrm{HT}+\mathrm{CT}$ incubations (35.0, 40.1, and 10.8 in HT + CT1, HT + CT2, and HT + CT3, respectively; Table 3). There was an increase of only $2.9 \%$ in the total bacterial population in the HT incubations $(0.1,0.1$, and $8.7 \%$ in HT1, HT2, and HT3, respectively), whereas it was $30.0 \%$ ( $P$ $<0.001)$ in the HT + CT incubations $(35.0,13.0$, and $42.3 \%$ in HT + CT1, HT + CT2, and HT + CT3, respectively; Table 3). Incubations containing tannin had reduced total ciliated protozoal counts compared with incubations with added PEG-6000. The mean decrease in ciliated protozoal numbers was $12.3 \%$ in HT samples and was $36.2 \%$ in HT + CT samples.

\section{In Vitro $\mathrm{pH}$, Gas Production, $\mathrm{NH}_{3}-\mathrm{N}$ and VFA Concentrations, and IVDMD}

The final $\mathrm{pH}$ and the $\mathrm{NH}_{3}-\mathrm{N}(\mathrm{mg} / \mathrm{dL})$, total VFA $(\mathrm{m} M)$, and individual VFA $(\mathrm{m} M)$ concentrations from incubations with and without PEG-6000 addition are shown in Table 4. Tannins increased $\mathrm{pH}$, reduced $(P$ $<0.001)$ VFA concentrations, and tended to increase the molar proportion of propionate compared with the PEG-6000-supplemented incubations. The proportion of butyrate was not affected. Concentrations of isoacids decreased $(P<0.001)$ in the presence of tannin.

When the basal diet (no tannin) was incubated with incremental levels of HT + CT1, HT + CT2, and HT $+\mathrm{CT} 3$, total gas production, $\mathrm{CH}_{4}$ output $(\mathrm{m} M / \mathrm{g}$ of DM incubated), and archaea and protozoal populations decreased as the concentration of tannin increased (Tables 5, 6, and 7), except in incubations with HT + CT3. The magnitude of the change varied at lower levels (up to 10\%) among 3 tannin sources; however, at $25 \%$ inclusion, $\mathrm{CH}_{4}$ production $(1.05 \mathrm{mM} / \mathrm{g}$ of $\mathrm{DM})$ was similar among all samples. In contrast to PEG-6000 addition to tannin samples, the total bacterial population decreased when the tannin concentration increased in the HT + CT1 and HT + CT3 incubations, but no specific trend was observed in the HT + CT2 incubations. There was a decrease in $\mathrm{CH}_{4}$ concentration up to $10 \%$ tannin inclusion in $\mathrm{HT}+\mathrm{CT} 1, \mathrm{HT}+\mathrm{CT} 2$, and $\mathrm{HT}+\mathrm{CT} 3$, and at higher levels the concentration plateaued. In vitro DM digestibility indicated no change at lower levels of tannin inclusion; however, at higher levels $(>15 \%)$, DM digestibility decreased $(P<0.001)$, except in the HT + CT3 incubation.

The correlations between total tannin ( $\%$ of TMR), archaea population (\% of total bacteria), and $\mathrm{CH}_{4}$ output $(\mathrm{m} M / \mathrm{g}$ of DM) are presented in Table 8 . There was a negative correlation between total tannins and the archaea population and $\mathrm{CH}_{4}$ output, indicating that as tannin concentration increased, the archaea population and $\mathrm{CH}_{4}$ output decreased. The correlation was highest $(\mathrm{r}=0.90)$ in HT + CT2 compared with HT + CT1 (r $=0.85)$ and HT + CT3 $(\mathrm{r}=0.42)$.

The effect of graded levels of HT + CT1, HT + CT2, and $\mathrm{HT}+\mathrm{CT} 3$ in the basal diet on $\mathrm{NH}_{3}-\mathrm{N}, \mathrm{pH}$, and VFA are presented in Tables 5, 6, and 7, respectively. Increasing the tannin level resulted in reduced $\mathrm{NH}_{3-}$ $\mathrm{N}$ and VFA concentrations. There was a decrease in acetic acid and an increase in propionic acid concentration with tannin supplementation. The concentration of iso-acids also decreased when tannin concentration increased.

\section{DISCUSSION}

Samples containing HT $+\mathrm{CT}$ were more effective in reducing total gas and $\mathrm{CH}_{4}$ production than samples containing HT only. The effects of HT $+\mathrm{CT}$ on total gas and $\mathrm{CH}_{4}$ production were greater compared with HT. In an earlier study, we showed that in vitro incubations with tamarind (Tamarindus indica) seed husk (containing approximately $140 \mathrm{~g}$ of $\mathrm{CT} / \mathrm{kg}$ of $\mathrm{DM}$ ), had lower gas production compared with incubations that had the added tannin-binder PEG (Bhatta et al., 2001). Waghorn et al. (2002) reported that in vitro incubation of Lotus pedunculatus (containing tannin) had lower $\mathrm{CH}_{4}$ production compared with L. pedunculatus treated with PEG. In the same study, sheep fed L. pedunculatus produced $17 \%$ less $\mathrm{CH}_{4}$ compared with sheep fed L. pedunculatus plus PEG. Very few reports are available regarding the biological activities of tannin fractions on ruminal $\mathrm{CH}_{4}$ production. Extracts of HT, such as gallotannic acid, showed $50 \%$ inhibition of $\mathrm{CH}_{4}$ production, with lower inhibition associated with monomers compared with polymers (Field and Lettinga, 1987). Further studies are needed with fraction- 
Table 4. In vitro $\mathrm{pH}, \mathrm{NH}_{3}-\mathrm{N}(\mathrm{mg} / \mathrm{dL})$, and VFA production $(\mathrm{m} M)$ in fermentations of tannin samples ${ }^{1}$ with and without polyethylene glycol $(\mathrm{PEG})^{2}$

\begin{tabular}{|c|c|c|c|c|c|c|c|c|c|c|c|c|c|}
\hline \multirow[b]{2}{*}{ Sample } & \multicolumn{6}{|c|}{$\mathrm{HT}^{3}$} & \multicolumn{6}{|c|}{$\mathrm{HT}+\mathrm{CT}^{4}$} & \multirow[b]{2}{*}{ SEM } \\
\hline & HT1 & $\begin{array}{c}\mathrm{HT} 1+ \\
\text { PEG }\end{array}$ & HT2 & $\begin{array}{c}\mathrm{HT} 2+ \\
\text { PEG }\end{array}$ & HT3 & $\begin{array}{c}\text { HT3 + } \\
\text { PEG }\end{array}$ & $\begin{array}{l}\mathrm{HT}+ \\
\mathrm{CT} 1\end{array}$ & $\begin{array}{c}\mathrm{HT}+\mathrm{CT} 1 \\
+ \text { PEG }\end{array}$ & $\begin{array}{c}\mathrm{HT}+ \\
\mathrm{CT} 2\end{array}$ & $\begin{array}{c}\mathrm{HT}+\mathrm{CT} 2 \\
+\mathrm{PEG}\end{array}$ & $\begin{array}{c}\mathrm{HT}+ \\
\mathrm{CT} 3\end{array}$ & $\begin{array}{c}\mathrm{HT}+ \\
\mathrm{CT} 3+ \\
\text { PEG }\end{array}$ & \\
\hline $\mathrm{pH}$ & $6.72^{\mathrm{a}}$ & $6.59^{\mathrm{ab}}$ & $6.73^{\mathrm{a}}$ & $6.65^{\mathrm{a}}$ & $6.44^{\mathrm{bc}}$ & $6.03^{\mathrm{d}}$ & $6.68^{\mathrm{a}}$ & $6.58^{\mathrm{ab}}$ & $6.68^{\mathrm{ab}}$ & $6.62^{\mathrm{ab}}$ & $6.37^{\mathrm{c}}$ & $6.31^{\mathrm{c}}$ & 0.039 \\
\hline $\mathrm{NH}_{3}-\mathrm{N}$ & $3.93^{\text {cde }}$ & $4.83^{\mathrm{b}}$ & $4.08^{\mathrm{cd}}$ & $4.98^{\mathrm{b}}$ & $3.75^{\mathrm{e}}$ & $3.84^{\text {de }}$ & $4.02^{\mathrm{cd}}$ & $5.07^{\mathrm{b}}$ & $3.18^{\mathrm{f}}$ & $5.46^{\mathrm{a}}$ & $4.14^{\mathrm{c}}$ & $5.37^{\mathrm{a}}$ & 0.055 \\
\hline Total VFA ${ }^{5}$ & $46.3^{\mathrm{c}}$ & $83.5^{\mathrm{a}}$ & $47.4^{\mathrm{c}}$ & $78.5^{\mathrm{ab}}$ & $45.0^{\mathrm{c}}$ & $76.9^{\mathrm{ab}}$ & $43.0^{\mathrm{c}}$ & $79.1^{\mathrm{ab}}$ & $48.1^{\mathrm{c}}$ & $77.2^{\mathrm{ab}}$ & $41.8^{\mathrm{c}}$ & $72.3^{\mathrm{b}}$ & 1.397 \\
\hline $\mathrm{C} 2: \mathrm{C} 3$ & $3.85^{\mathrm{bc}}$ & $4.03^{\mathrm{b}}$ & $3.78^{\text {bc }}$ & $4.05^{\mathrm{b}}$ & $4.27^{\mathrm{b}}$ & $5.30^{\mathrm{a}}$ & $4.12^{\mathrm{b}}$ & $5.18^{\mathrm{a}}$ & $3.30^{\mathrm{c}}$ & $4.34^{\mathrm{b}}$ & $4.17^{\mathrm{b}}$ & $5.27^{\mathrm{a}}$ & 0.132 \\
\hline $\mathrm{C} 4$ & $5.1^{\mathrm{bcd}}$ & $6.0^{\mathrm{ab}}$ & $5.1^{\mathrm{bcd}}$ & $4.9^{\mathrm{cd}}$ & $4.35^{\mathrm{d}}$ & $5.7^{\mathrm{abc}}$ & $4.1^{\mathrm{d}}$ & $6.3^{\mathrm{a}}$ & $6.0^{\mathrm{ab}}$ & $5.5^{\mathrm{abc}}$ & $4.1^{\mathrm{d}}$ & $5.5^{\mathrm{abc}}$ & 0.202 \\
\hline C5 & $0^{\mathrm{b}}$ & $0.7^{\mathrm{ab}}$ & $0.2^{\mathrm{b}}$ & $0.4^{\mathrm{ab}}$ & $0.4^{\mathrm{ab}}$ & $0.9^{\mathrm{a}}$ & $0^{\mathrm{b}}$ & $0.5^{\mathrm{ab}}$ & $0^{\mathrm{b}}$ & $0.7^{\mathrm{ab}}$ & $0^{\mathrm{b}}$ & $0.4^{\mathrm{ab}}$ & 0.138 \\
\hline $\mathrm{iC} 4+\mathrm{iC} 5$ & $1.2^{\mathrm{c}}$ & $2.0^{\mathrm{bc}}$ & $0.7^{\mathrm{c}}$ & $1.0^{\mathrm{c}}$ & $1.6^{\mathrm{c}}$ & $4.2^{\mathrm{a}}$ & $0.5^{\mathrm{c}}$ & $3.9^{\mathrm{a}}$ & $0.7^{\mathrm{c}}$ & $1.2^{\mathrm{c}}$ & $0.6^{\mathrm{c}}$ & $3.3^{\mathrm{ab}}$ & 0.339 \\
\hline
\end{tabular}

${ }^{\mathrm{a}-\mathrm{f}}$ Means within a row without a common superscript letter differ $(P<0.001)$.

${ }^{1} \mathrm{HT}=$ hydrolyzable tannin as gallotannin; $\mathrm{CT}=$ condensed tannin as leucocyanidin equivalent.

${ }^{2}$ Tannin sample and PEG (PEG-6000; Wako Pure Chemical Industries Ltd., Osaka, Japan) were incubated at a 1:2 ratio (wt/wt).

${ }^{3} \mathrm{HT} 1, \mathrm{HT} 2$, and HT3 = samples containing only HT (HT1 from myrabolam; HT2 and HT3 from chestnut).

${ }^{4} \mathrm{HT}+\mathrm{CT} 1, \mathrm{HT}+\mathrm{CT} 2, \mathrm{HT}+\mathrm{CT} 3=$ samples containing HT plus CT $(\mathrm{HT}+\mathrm{CT} 1$ and HT + CT2 from quebracho; HT + CT3 from mimosa).

${ }^{5} \mathrm{C} 2=$ acetic acid; $\mathrm{C} 3=$ propionic acid; $\mathrm{C} 4=$ butyric acid; $\mathrm{C} 5=$ valeric acid; $\mathrm{iC} 4+\mathrm{iC} 5=$ isobutyric + isovaleric acids.

ated extracts from the tannin samples to identify the specific component(s) responsible for antimethanoginic activity.

Reports on the effects of $\mathrm{HT}$ and $\mathrm{CT}$ on ruminal ciliated protozoal counts are somewhat conflicting. Extracts containing HT were reported to have no significant effect on protozoal counts (Sliwinski et al., 2002), whereas Leinmuller et al. (1991) reported HT as less inhibitory than CT on protozoal numbers. However, Terrill et al. (1992) did not observe any adverse effect of CT-containing sulla (Hadysarum coronarium) on protozoal numbers. In our study, differences in protozoal numbers observed between tannin-containing samples and tannin plus PEG-6000 incubations confirmed that the effects of $\mathrm{HT}$ and $\mathrm{CT}$ on protozoal populations were not similar, with HT + CT exhibiting greater antiprotozoal activity than HT only. This difference in the effects of HT + CT- and HT-containing tannin samples on protozoal populations likely contributed to the difference in antimethanogenic activity observed in our incubations. Protozoa contribute hydrogen for the reduction of $\mathrm{CO}_{2}$ to $\mathrm{CH}_{4}$ by the methanogens. Methane production is higher when protozoa are present or present in greater numbers in the rumen than when they are absent or present in low in numbers (Jouany and Lassalas, 1997).

Tannins decreased in vitro $\mathrm{NH}_{3}-\mathrm{N}$ concentrations in all incubations compared with PEG-6000-supplemented incubations; however, the magnitude of decrease was greater in $\mathrm{HT}+\mathrm{CT}$ incubations than in $\mathrm{HT}$ incubations alone (Table 4). A similar trend was also observed when the basal diet was incubated with increased levels of samples containing HT $+\mathrm{CT}$. This can be attributed to the formation of complexes between $\mathrm{HT}$ and $\mathrm{CT}$ with proteins. The HT and proteins usually form complexes at an optimal $\mathrm{pH}$ range of 3 to 4 , but complexes also occur in appreciable amounts under typical rumen $\mathrm{pH}$ of 6 to 7 (Leinmuller and Menke, 1990). Some ruminal bacteria can dissociate the protein-HT complexes, thus indicating that the formation of these complexes is at least partially reversible. However, the dissociation of protein-CT complexes is difficult (McSweeny et al., 2001). The observed difference in $\mathrm{NH}_{3}-\mathrm{N}$ concentrations between $\mathrm{HT}$ and $\mathrm{HT}+\mathrm{CT}$ may be attributable to the reversible nature of the protein-HT complex.

In the absence of tannin (or when bound with PEG6000 ), the degradability of protein was higher, resulting in a greater $\mathrm{NH}_{3}-\mathrm{N}$ concentration, possibly because of inhibition of microbial deaminase by tannins (Leinmuller and Menke, 1990). When sheep were changed from a diet of perennial rye grass and white clover (which did not contain CT) to a diet of Lotus corniculatus containing CT (32 g of CT $/ \mathrm{kg}$ of $\mathrm{DM}$ ), the population of ruminal proteolytic Butyrivibrio fibrisolvens decreased. When PEG was infused into the rumen, populations of those proteolytic bacteria increased significantly (Min et al., 2003). Low $\mathrm{NH}_{3}-\mathrm{N}$ was also reported in sheep (Bhatta et al., 2007) and goats (Bhatta et al., 2002, 2005) consuming tannin-containing Prosopis cineraria leaves (10 g of $\mathrm{CT} / \mathrm{kg}$ of $\mathrm{DM})$. Ewes grazing the CTcontaining forage $L$. corniculatus showed lower ruminal $\mathrm{NH}_{3}$ concentrations than ewes grazing CT-free forage 
Table 5. Effects of hydrolyzable plus condensed tannin $(\mathrm{HT}+\mathrm{CT} 1)$ on in vitro $\mathrm{CH}_{4}$ production and rumen microbial population

\begin{tabular}{|c|c|c|c|c|c|c|c|c|}
\hline Item & \multicolumn{6}{|c|}{ Tannin concentration $^{1}$ ( $\%$ of $\mathrm{TMR}^{2}{ }^{2} \mathrm{DM}$ basis) } & SEM & $P$-value \\
\hline $\begin{array}{l}\text { 24-h gas production }(\mathrm{mL} / 200 \mathrm{mg} \text { of } \mathrm{DM}) \\
\mathrm{CH}_{4}\end{array}$ & $40.8^{\mathrm{a}}$ & $39.0^{\mathrm{ab}}$ & \multicolumn{2}{|c|}{$\mathrm{CH}_{4}$} & $34.8^{\mathrm{bc}}$ & $32.7^{\mathrm{c}}$ & 0.920 & 0.0005 \\
\hline$\%$ of total gas & 17.7 & 17.0 & 16.2 & 17.0 & 16.9 & 17.2 & 0.324 & 0.1317 \\
\hline $\mathrm{m} M / \mathrm{g}$ of $\mathrm{DM}$ & $1.70^{\mathrm{a}}$ & $1.48^{\mathrm{b}}$ & $1.31^{\mathrm{bc}}$ & $1.25^{\mathrm{cd}}$ & $1.17^{\mathrm{cd}}$ & $1.05^{\mathrm{d}}$ & 0.043 & 0.0001 \\
\hline Archaeal population ( $\%$ of $16 \mathrm{~S}$ rRNA) & $12.5^{\mathrm{a}}$ & $12.6^{\mathrm{a}}$ & $8.3^{\mathrm{b}}$ & $9.3^{\mathrm{b}}$ & $9.7^{\mathrm{b}}$ & $8.7^{\mathrm{b}}$ & 0.397 & 0.0001 \\
\hline IVDMD $^{3}$ & $0.665^{\mathrm{a}}$ & $0.664^{\mathrm{a}}$ & $0.655^{\mathrm{a}}$ & $0.651^{\mathrm{a}}$ & $0.640^{\mathrm{b}}$ & $0.630^{\mathrm{b}}$ & 0.009 & 0.0005 \\
\hline \multicolumn{9}{|l|}{ Fermentation product ${ }^{4}$} \\
\hline $\mathrm{pH}$ & 6.32 & 6.32 & 6.35 & 6.37 & 6.34 & 6.33 & 0.022 & 0.556 \\
\hline $\mathrm{NH}_{3}-\mathrm{N}(\mathrm{mg} / \mathrm{dL})$ & $8.18^{\mathrm{a}}$ & $7.27^{\mathrm{b}}$ & $6.85^{\mathrm{bc}}$ & $6.71^{\mathrm{bc}}$ & $6.65^{\mathrm{bc}}$ & $6.36^{\mathrm{c}}$ & 0.170 & 0.001 \\
\hline Total VFA $(\mathrm{m} M)$ & $66.7^{\mathrm{a}}$ & $65.4^{\mathrm{ab}}$ & $63.0^{\mathrm{abc}}$ & $62.4^{\mathrm{abc}}$ & $60.6^{\mathrm{bc}}$ & $57.4^{\mathrm{c}}$ & 1.209 & 0.002 \\
\hline $\mathrm{C} 2(\mathrm{~m} M)$ & $43.8^{\mathrm{a}}$ & $43.4^{\mathrm{a}}$ & $41.5^{\mathrm{ab}}$ & $41.5^{\mathrm{ab}}$ & $40.2^{\mathrm{ab}}$ & $38.0^{\mathrm{b}}$ & 0.767 & 0.002 \\
\hline $\mathrm{C} 3(\mathrm{~m} M)$ & $12.2^{\mathrm{a}}$ & $12.1^{\mathrm{a}}$ & $11.8^{\mathrm{ab}}$ & $11.8^{\mathrm{ab}}$ & $11.4^{\mathrm{ab}}$ & $10.8^{\mathrm{b}}$ & 0.229 & 0.010 \\
\hline
\end{tabular}

${ }^{\mathrm{a}-\mathrm{f}}$ Means within a row without a common superscript letter differ $(P<0.001)$.

${ }^{1} 0,5,10,15,20$, and $25=$ level of tannin sample containing hydrolyzable and condensed tannin (HT + CT1 from quebracho) as a percentage of TMR on a DM basis (wt/wt).

${ }^{2}$ TMR contained 65 parts timothy hay, 20 parts crushed corn, and 15 parts soybean meal.

${ }^{3} \mathrm{IVDMD}=$ in vitro DM digestibility after $48 \mathrm{~h}$.

${ }^{4} \mathrm{C} 2=$ acetic acid; $\mathrm{C} 3=$ propionic acid; $\mathrm{C} 4=$ butyric acid; $\mathrm{C} 5=$ valeric acid; $\mathrm{iC} 4+\mathrm{iC} 5=$ isobutyric + isovaleric acids.

Table 6. Effects of hydrolyzable plus condensed tannin $(\mathrm{HT}+\mathrm{CT} 2)$ on in vitro $\mathrm{CH}_{4}$ production, rumen microbial population, and fermentation products

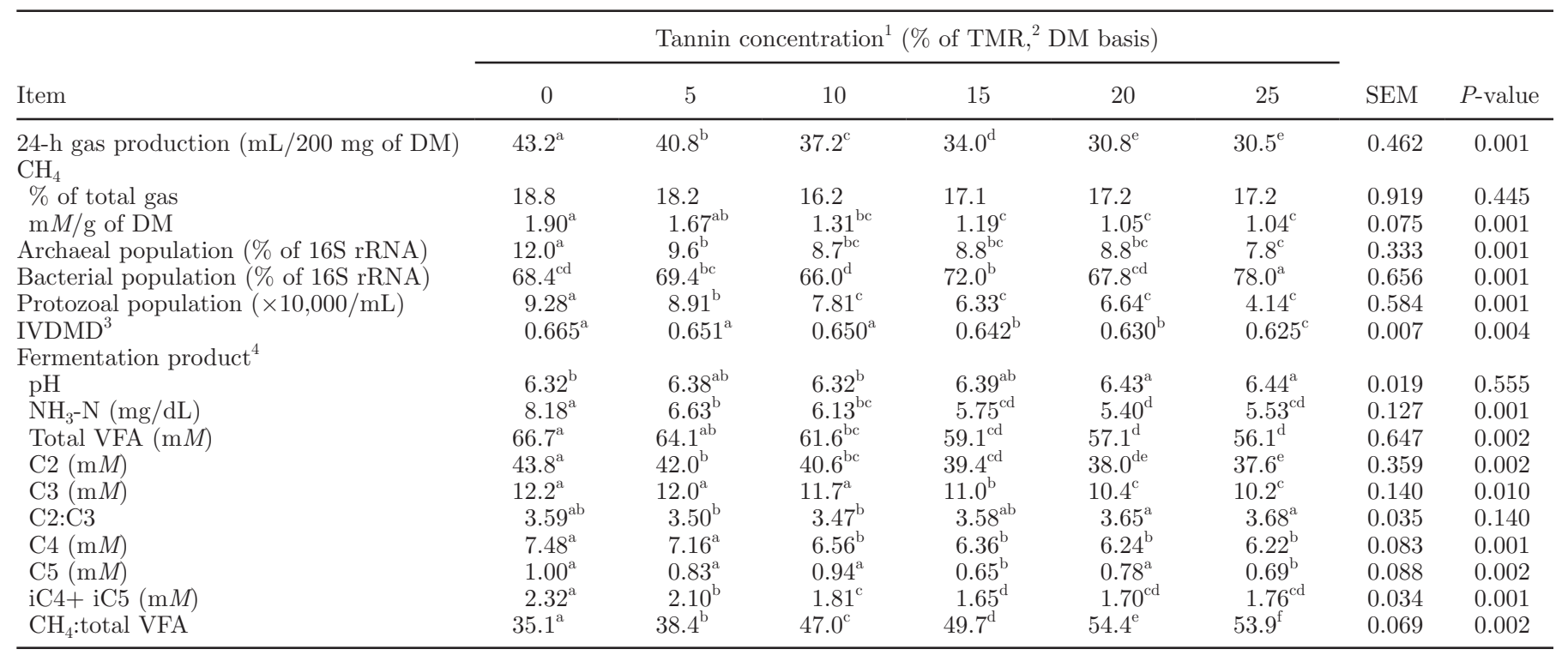

${ }^{\mathrm{a}-\mathrm{f}}$ Means within a row without a common superscript letter differ $(P<0.001)$.

${ }^{1} 0,5,10,15,20$, and $25=$ level of tannin sample containing hydrolyzable and condensed tannin (HT + CT2 from quebracho) as a percentage of TMR on a DM basis (wt/wt).

${ }^{2} \mathrm{TMR}$ contained 65 parts timothy hay, 20 parts crushed corn, and 15 parts soybean meal.

${ }^{3} \mathrm{IVDMD}=$ in vitro DM digestibility after $48 \mathrm{~h}$.

${ }^{4} \mathrm{C} 2=$ acetic acid; $\mathrm{C} 3=$ propionic acid; $\mathrm{C} 4=$ butyric acid; $\mathrm{C} 5=$ valeric acid; $\mathrm{iC} 4+\mathrm{iC} 5=$ isobutyric + isovaleric acids. 
Table 7. Effects of hydrolyzable plus condensed tannin $(\mathrm{HT}+\mathrm{CT} 3)$ on in vitro $\mathrm{CH}_{4}$ production, rumen microbial population, and fermentation products

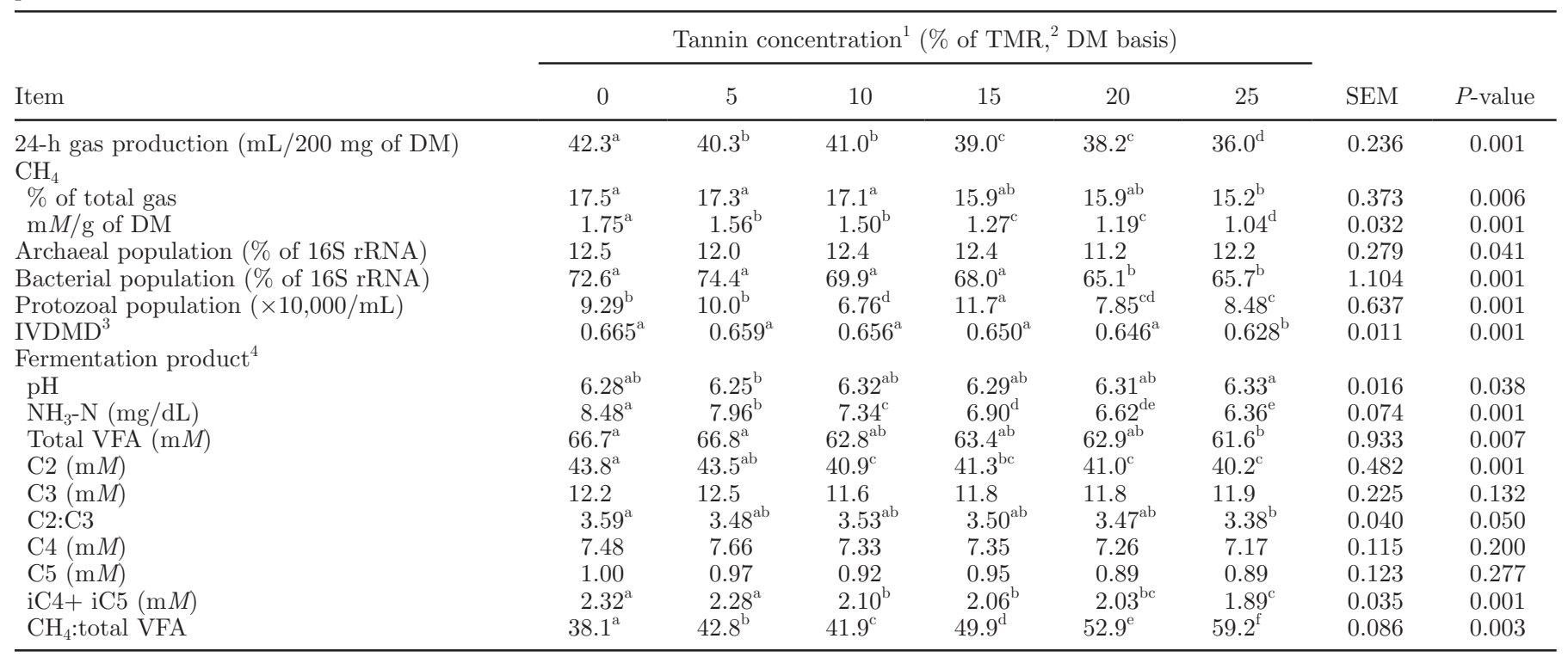

${ }^{\mathrm{a}-\mathrm{f}}$ Means within a row without a common superscript letter differ $(P<0.001)$.

${ }^{1} 0,5,10,15,20$, and $25=$ level of tannin sample containing hydrolyzable and condensed tannin (HT + CT3 from mimosa) as a percentage of TMR on a DM basis (wt/wt).

${ }^{2}$ TMR contained 65 parts timothy hay, 20 parts crushed corn, and 15 parts soybean meal.

${ }^{3} \mathrm{IVDMD}=$ in vitro DM digestibility after $48 \mathrm{~h}$.

${ }^{4} \mathrm{C} 2=$ acetic acid; $\mathrm{C} 3=$ propionic acid; $\mathrm{C} 4=$ butyric acid; $\mathrm{C} 5=$ valeric acid; iC4+ iC5 $=$ isobutyric + isovaleric acids.

(Min et al., 1998). The significant decrease in the $\mathrm{NH}_{3}-\mathrm{N}$ concentration may be attributed to inhibition of the bacteria-degrading activity of protozoa (Jouany, 1994).

Total bacterial counts were greater $(P<0.001)$ and protozoal counts were lower (except for HT3) in the presence of tannin (no PEG-6000). The reduction in concentrations of iso-acids further supports our findings. Iso-acids are derived from AA catabolism in the rumen (Mackie and White, 1990). Concentrations of iso-acids were lower in the presence of tannin because the protein was protected from ruminal deamination. Results were also similar when the basal diet (without tannin) was incubated with graded levels HT + CT. The maximum concentration of iso-acids was reported with nontanniferous legumes, whereas lower concentrations were found in legumes with high CT (Tavendale et al., 2005). In our study, reductions in iso-acids were recorded only in $\mathrm{HT}+\mathrm{CT}$, but not in $\mathrm{HT}$, again reflecting the difference in the type of tannins.

The reduction in $\mathrm{pH}$ after PEG-6000 addition was due to greater VFA production. Tannins tended to increase the molar proportion of propionate. A similar trend was observed when the basal diet (no tannin) was incubated with graded levels of tannin. Lower propionate production in the presence of PEG has also been reported (Nuñez-Hernandez et al., 1991). Production of methane and propionate is negatively correlated because of the competition for hydrogen. Additionally, enhanced propionate production is associated with an increase in the flow of microbial protein from the rumen (Tavendale et al., 2005). Protozoa were responsible for the shift in VFA proportions toward acetic and butyric acids. Further, the transfer of hydrogen to archaea is facilitated by a synergistic interaction between methanogens and ciliates (Vogels et al., 1980). The positive relationship between the acetic acid:propionic acid ratio and $\mathrm{CH}_{4}$ output is also clearly evident from our results.

Samples containing HT + CT exhibited greater antimethanogenic activity than HT alone, whereas the effects on other ruminal microbes appeared less severe. Our results suggest that reduced $\mathrm{CH}_{4}$ production with tannin was primarily due to its antimethanogenic activ-

Table 8. Correlation between total tannins ${ }^{1}$ ( $\%$ of TMR, DM basis), archaeal population, and $\mathrm{CH}_{4}$ output

\begin{tabular}{|c|c|c|c|}
\hline Item & $\mathrm{HT}+\mathrm{CT} 1$ & $\mathrm{IT}+\mathrm{CT} 2$ & $\mathrm{HT}+\mathrm{CT} 3$ \\
\hline $\begin{array}{l}\text { Total tannins:archaeal } \\
\text { population }\end{array}$ & -0.758 & -0.860 & -0.430 \\
\hline Total tannins: $\mathrm{CH}_{4}$ output & -0.976 & -0.954 & -0.991 \\
\hline Archaeal population: $\mathrm{CH}_{4}$ output & 0.849 & 0.903 & 0.419 \\
\hline
\end{tabular}

${ }^{1} \mathrm{HT}+\mathrm{CT} 1, \mathrm{HT}+\mathrm{CT} 2$, and $\mathrm{HT}+\mathrm{CT} 3=$ samples containing hydrolyzable plus condensed tannin $(\mathrm{HT}+\mathrm{CT} ; \mathrm{HT}+\mathrm{CT} 1$ and $\mathrm{HT}+\mathrm{CT} 2$ from quebracho; HT + CT3 from mimosa). 
ity, and not solely because of reduced fermentation of OM, as reported in earlier studies. Ultee et al. (2002) noted that compounds with phenolic structures were more effective as antimicrobials in comparison with other nonphenolic secondary plant metabolites because of the presence of a hydroxyl group in the phenolic structure. Methanogenic archaea are associated symbiotically with the ciliate protozoa on the surface (ectosymbionts) and inside the protozoa (endosymbionts; Finlay et al., 1994); hence, a reduction in protozoal counts may decrease archaeal counts as well. In the presence of tannin, both protozoal and archaeal numbers were reduced, which likely led to a compensatory increase in the population of other ruminal bacteria (Jouany, 1994). However, Soliva et al. (2004) did not find an increase in the bacterial population after suppression of protozoa, and this was attributed to an adverse effect of tannins on some bacterial species as well. In our second experiment, in which graded levels of the tannin source $(\mathrm{HT}+\mathrm{CT})$ were incubated with the basal diet, there was no increase in bacterial counts despite the suppression of protozoa. A similar observation was made by Soliva et al. (2004).

When the basal diet was incubated with graded levels of HT + CT1, HT + CT2, and HT + CT3, the total gas and $\mathrm{CH}_{4}$ produced and the archaeal and protozoal populations decreased. There was a decline in $\mathrm{CH}_{4}$ output from the 0 to $10 \%$ level of HT + CT1 and HT + CT2 samples and thereafter a plateau, whereas in HT + CT3, the decrease was gradual. Hayler et al. (1998) reported that the amount of $\mathrm{CH}_{4}$ produced per unit of fermented substrate in vitro was lower as the level of tannin-containing feed in the mixture increased. Differences in $\mathrm{CH}_{4}$ production among samples were attributed to variations in content of tannins and their biological activity. The IVDMD values reflected an adverse effect of tannins only at greater levels. This further confirmed that the suppression of $\mathrm{CH}_{4}$ recorded at a lower level of tannins was primarily due to the antimethanogenic and antiprotozoal activities of the tannins, leading to the decrease in methanogenic archaea counts, but at greater levels, it was likely due to the combined effect of decreased ruminal microbes (archaea + protozoa) and decreased $\mathrm{OM}$ fermentation. The ratios of $\mathrm{CH}_{4}$ to total VFA depicted in Tables 5, 6, and 7 confirm this finding.

A suitable compound for inhibition of methanogenesis in meat-producing animals would be one that is effective in reducing $\mathrm{CH}_{4}$ production and one that also increases propionate (Tavendale et al., 2005). The tannin sources tested in our studies appear to have those attributes for use in ruminant feeding to suppress methanogenesis. However, it must be noted that the long-term effects might be different because adaptation of the rumen microbes might occur. Therefore, longterm feeding trials in animals need to be carried out to determine their effects on animal response and also to observe changes in the rumen microbial population.

\section{CONCLUSIONS}

Our investigation confirmed that tannins suppress methanogenesis directly through their antimethanogenic activity and indirectly through their antiprotozoal activity. Samples containing HT + CT were more potent in reducing methanogenesis than those containing HT only. Incubation of the basal diet (no tannin) with graded levels of the tannin source showed a linear response on $\mathrm{CH}_{4}$ suppression. Further studies need to be carried out to identify the specific chemical component responsible for and mechanism of action of antimethanogenic activity. In addition, animal feeding studies are needed to determine the long-term effects on rumen microbial populations and animal performance.

\section{ACKNOWLEDGMENTS}

This study was supported by the Global Environment Research Fund from the Ministry of Environment (Tokyo, Japan) and the research fund from the Ministry of Agriculture, Forestry and Fisheries of Japan (Tokyo). Raghavendra Bhatta is grateful to the Japan Society for the Promotion of Science (JSPS; Tokyo) for awarding the JSPS postdoctoral research fellowship. The technical assistance of E. Nirasawa and T. Shimada and the help of the staff of the animal shed for the care and management of the cannulated animals are acknowledged. The guidance of Robin C. Anderson, USDA (Texas) and T. G. Nagaraja, Kansas State University (Manhattan), in editing the manuscript is gratefully acknowledged.

\section{REFERENCES}

Anderson, R. C., T. R. Callaway, J. A. Van Kessel, Y. S. Jung, T. S. Edrington, and D. J. Nisbet. 2003. Effect of select nitro compounds on ruminal fermentation: An initial look at their potential to reduce economic and environmental costs associated with ruminal methanogenesis. Bioresour. Technol. 90:59-63.

AOAC. 1990. Official Methods of Analysis. 15th ed. Assoc. Off. Anal. Chem., Washington, DC.

Baker, S. K. 1999. Rumen methanogens and inhibition of methanogenesis. Aust. J. Agric. Res. 50:1293-1298.

Bhatta, R., U. Krishnamoorthy, and F. Mohammed. 2001. Effect of tamarind (Tamarindus indica) seed husk tannins on in vitro rumen fermentation. Anim. Feed Sci. Technol. 90:143-152.

Bhatta, R., A. K. Shinde, S. Vaithiyanathan, S. K. Sankhyan, and D. L. Verma. 2002. Effect of polyethylene glycol-6000 on nutrient intake, digestion and growth of kids browsing Prosopis cineraria. Anim. Feed Sci. Technol. 101:45-54.

Bhatta, R., S. Vaithiyanathan, A. K. Shinde, and R. C. Jakhmola. 2005. Effect of feeding complete feed block containing Prosopis cineraria leaves and polyethylene glycol (PEG)-6000 on nutrient 
intake, its utilization, rumen fermentation pattern and rumen enzyme profile in kids. J. Sci. Food Agric. 85:1788-1794.

Bhatta, R., S. Vaithiyanathan, N. P. Singh, and D. L. Verma. 2007. Effect of feeding complete diets containing graded levels of Prosopis cineraria leaves on feed intake, nutrient utilization and rumen fermentation in lambs and kids. Small Rumin. Res. 67:75-83.

Field, J. A., and G. Lettinga. 1987. The methanoginic toxicity and anaerobic degradability of hydrolysable tannin. Water Res. $21: 367-374$.

Finlay, B. J., G. Esteban, K. J. Clarke, A. G. Williams, T. M. Embley, and R. P. Hirt. 1994. Some rumen ciliates have endosymbiotic methanogens. FEMS Microbiol. Lett. 117:157-161.

Hayler, R., H. Steingass, and W. Drochner. 1998. Effects of various feedstuffs rich in tannin content on rumen methanogenesis in vitro using the Hohenheim test. Proc. Soc. Nutr. Physiol. 7:35.

Joblin, K. N. 1999. Ruminal acetogens and their potential to lower ruminant methane emissions. Aust. J. Agric. Res. 50:1307-1313.

Jouany, J. P. 1994. Manipulation of microbial activity in the rumen Arch. Anim. Nutr. 46:133-153.

Jouany, J. P., and B. Lassalas. 1997. Study of the adaptation of the rumen ecosystem to the antimethanoginic effect of monensin measured in vivo. Reprod. Nutr. Dev. 37(Suppl. 1):S69-S70.

Kajikawa, H., K. Tajima, M. Mitsumori, and A. Takenaka. 2007. Effects of amino nitrogen on fermentation parameters by mixed ruminal microbes when energy or nitrogen is limited. Anim. Sci. J. $78: 121-128$.

Krause, D. O., and J. B. Russell. 1996. An rRNA approach for assessing the role of obligate amino acid-fermenting bacteria in ruminal amino acid deamination. Appl. Environ. Microbiol. 62:815-821.

Lassey, K. R. 2007. Livestock methane emission: From the individual grazing animal through national inventories to the global methane cycle. Agric. For. Meteorol. 142:120-132.

Leinmuller, E., and K. H. Menke. 1990. Tannine in Futtermittenln fur Wiederkauer. 1. Chemische Eigenschaften und Reaktionen mit Makromolekulen. Ubersichten Tierernahr. 18:91-114.

Leinmuller, E., H. Steingass, and K. H. Menke. 1991. Tannins in feeds for ruminants. II Effects on rumen metabolism in vitro. Ubersichten Tierernahr. 19:45-70.

Mackie, R. I., and B. A. White. 1990. Recent advances in rumen microbial ecology and metabolism: Potential impact on nutrient out put. J. Dairy Sci. 73:2971-2995.

Makkar, H. P. S. 2003. Quantification of tannins in tree and shrub foliage: A laboratory manual. Food and Agriculture Organization of the United Nations/International Atomic Energy Agency. Kluwer Academic Publishers, Dordrecht, the Netherlands.

McSweeny, C. S., B. Palmer, D. M. McNeill, and D. O. Krause. 2001. Microbial interaction with tannins: Nutritional consequences for ruminants. Anim. Feed Sci. Technol. 91:83-93.

Menke, K. H., L. Raab, A. Salewski, H. Steingass, D. Fritz, and W. Schneider. 1979. The estimation of digestibility and metabolizable energy content of ruminant feeding stuffs from the gas production when they are incubated with rumen inoculum in vitro. J. Agric. Sci. (Camb.) 93:217-222.

Menke, K. H., and H. Steingass. 1988. Estimation of the energetic feed values obtained from chemical analysis and in vitro gas production using rumen fluid. Anim. Res. Dev. 28:7-55.

Min, B. R., T. N. Barry, G. T. Attwoood, and W. C. McNabb. 2003 The effect of condensed tannins on the nutrition and health of ruminants fed fresh temperate forages: A review. Anim. Feed Sci. Technol. 106:3-19.

Min, B. R., T. N. Barry, W. C. McNabb, and P. D. Kemp. 1998 Effect of condensed tannins on the production of wool and on its processing characteristics in sheep grazing Lotus corniculatus. Aust. J. Agric. Res. 49:597-605.

Nuñez-Hernandez, G., J. D. Wallace, J. L. Holechek, M. L. Galyean, and M. Cardenas. 1991. Condensed tannins and nutrient utilization by lambs and goats fed low-quality diets. J. Anim. Sci. 69:11671177.

Ogimoto, K., and S. Imai. 1981. Atlas of Rumen Microbiology. Japan Scientific Societies Press, Tokyo, Japan.
Robertson, J. B., and P. J. Van Soest. 1981. The detergent system of analysis and its application to human foods. Pages 123-130 in The Analysis of Dietary Fiber in Food. W. P. T. James and O. Theander, ed. Marcel Dekker, New York, NY.

Roth, S., H. Steingassß, and W. Drochner. 2002. Minderung von Methane emission und optimierung der N-Versorgung bei Wiederkauern durch die Behandlung von Futtermitteln mit Tanninen. Pages 181-186 in 34 Hohenheimer Umwelttagung. R. Bocker, ed. . Verlag Gunter Heimbach, Stuttgart, Germany.

SAS Institute. 2004. SAS/STAT User's Guide, Release 9.1.3. SAS Institute Inc., Cary, NC

Schonhusen, U., R. Zitnan, S. Kuhla, W. Jentsch, M. Derno, and J. Voigt. 2003. Effects of protozoa on methane production in rumen and hindgut of calves around time of weaning. Arch. Anim. Nutr. $57: 279-295$

Sliwinski, B. J., R. S. Carla, A. Machmuller, and M. Kreuzer. 2002 Efficacy of plant extracts rich in secondary constituents to modify rumen fermentation. Anim. Feed Sci. Technol. 101:101-114.

Soliva, C. R., L. Meile, A. Cieslak, M. Kreuzer, and A. Machmuller. 2004. Rumen simulation technique study on the interactions of dietary lauric and myristic acid supplementation in suppressing ruminal methanogenesis. Br. J. Nutr. 92:689-700.

Tajima, K., I. Nonaka, K. Higuchi, N. Takusari, M. Kurihara, A. Takenaka, M. Mitsumori, H. Kajikawa, and R. I. Aminov. 2007. Influence of temperature and humidity on rumen bacterial diversity in Holstein heifers. Anaerobe 13:57-64.

Tavendale, M. H., L. P. Meagher, D. Pacheco, N. Walker, G. T. Attwood, and S. Sivakumaran. 2005. Methane production from in vitro rumen incubations with Lotus pedunculatus and Medicago sativa, and effects of extractable condensed tannin fractions on methanogenesis. Anim. Feed Sci. Technol. 123-124:403-419.

Teather, R. M., S. Mahadevan, J. D. Erfle, and F. D. Sauer. 1984 Negative correlation between protozoal and bacterial levels in rumen samples and its relation to the determination of dietary effects on the rumen microbial population. Appl. Environ. Microbiol. 47:566-570.

Terrill, T. H., G. B. Douglas, A. G. Foote, R. W. Purchas, G. F. Wilson, and T. N. Barry. 1992. Effect of condensed tannin upon body growth, wool growth and rumen metabolism in sheep grazing sulla (Hedysarum coronarium) and perennial pasture. J. Agric. Sci. (Camb.) 119:265-273.

Ultee, A., M. H. J. Bennik, and R. Moezelaar. 2002. The phenolic hydroxyl group of carvacrol is essential for action against the food-borne pathogen Bacillus cereus. Appl. Environ. Microbiol. 68:1561-1568

Uyeno, Y., Y. Sekiguchi, A. Sunaga, H. Yoshida, and Y. Kamagata. 2004. Sequence-specific cleavage of small-subunit (SSU) rRNA with oligonucleotides and RNAse $\mathrm{H}$ : A rapid and simple approach to SSU rRNA-based quantitative detection of microorganisms. Appl. Environ. Microbiol. 70:3650-3663.

Uyeno, Y., Y. Sekiguchi, K. Tajima, A. Takenaka, M. Kurihara, and Y. Kamagata. 2007. Evaluation of group-specific, 16S rRNAtargeted scissor probes for quantitative detection of predominant bacterial populations in dairy cattle rumen. J. Appl. Microbiol. 103:1995-2005.

Van Soest, P. J., J. B. Robertson, and B. A. Lewis. 1991. Methods for dietary fibre, neutral detergent fibre and non-starch polysaccharides in relation to animal nutrition. J. Dairy Sci. 74:3583-3597.

Vogels, G. D., W. F. Hoppe, and C. K. Stumm. 1980. Association of methanogenic bacteria with rumen ciliates. Appl. Environ. Microbiol. 39:123-128.

Waghorn, G. C., M. H. Tavendale, and D. R. Woodfield. 2002. Methanogenesis from forages fed to sheep. Proc. N. Z. Grassl. Assoc. 64:167-171.

Whitford, M. F., R. J. Forster, C. E. Beard, J. Gong, and R. M. Teather. 1998. Phylogenetic analysis of rumen bacteria by comparative sequence analysis of cloned rRNA genes. Anaerobe 4:153-163. 